\title{
Construction of Engineering Talent Cultivation System for Automotive Electronics Industry
}

\author{
J.X.Chen \& H.H.Jian \& Z.C.Sun \\ Clean Energy Automotive Engineering Center, Tongji University, P.R.C.
}

\begin{abstract}
With the rapid progress of automotive electronics industry in China, related majors in universities or colleges should setup an engineering talent cultivation system in order to accommodate the growing demand for engineering talents. Based on a compact-structured and layered talent cultivation system, venture courses that introduce general process, tools or developing methods in enterprises should be taken into consideration besides the traditional courses and engineering practice. As a result, venture course will make students possess engineering views and capabilities, so they can become excellent reserved engineers.
\end{abstract} KEYWORD: Engineering talent cultivation system; Layered structure; Venture course; Curriculum

\section{INTRODUCTION}

Automotive electronics industry makes a rapid progress in China now. The proportion of automotive electronics products in a car is rising continuously to the degree of nearly twenty percent. At the same time, the requirement for highly qualified engineering talents grows also very fast. In order to meet the demand of talents from automotive enterprises and automotive electronics companies, engineering education system should be set up including continuing education program and shorttime training etc. However, engineering education should be paid more attention in universities or colleges because it is most convenient and effective for these public institutions to realize such a talent cultivation mode for future engineers. According to the above, the construction of engineering talent cultivation system for major of automotive electronics in universities or colleges is an urgent affair to be solved now.

\section{LAYERED ENGINEERING TALENT CULTIVATION SYSTEM}

Education for undergraduates, master candidates and doctoral candidates are three phases in higher education system. Although they have different objectives, these three phases will cooperate more closely in engineering talent cultivation system, shaping like a layered pyramid in Automotive Studies School of Tongji University (See Figure 1).

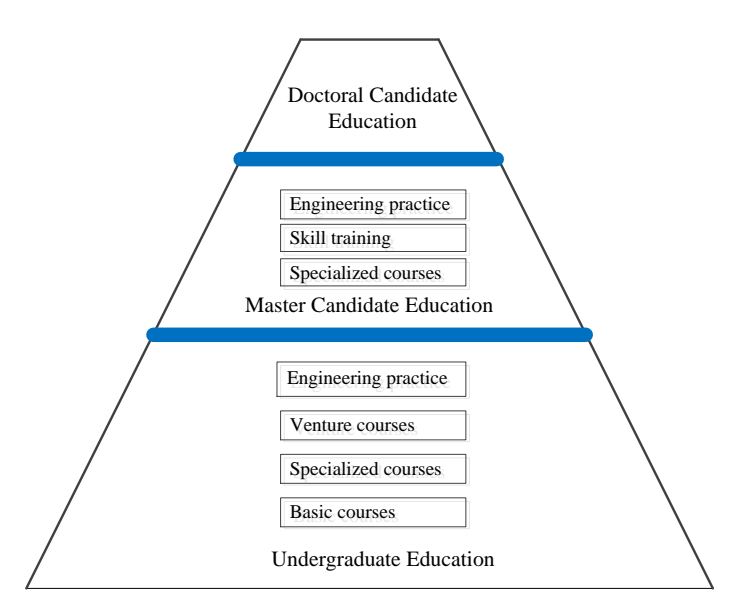

Figure 1 Layered engineering talent cultivation system

\subsection{Education for undergraduates}

In Figure 1, education for undergraduates locates in the bottom layer, acting as the base of the pyramid. There are two basic functions of this layer, one is to train plentiful qualified graduates with necessary theoretical foundation and enough engineering related background or experience, the other is to support higher education for master or doctoral candidates. Latter function reflects a close relationship among three layers in the cultivation system. Former function is realized by four modules: basic courses, specialized courses, venture courses and engineering practice. Basic courses teach engineering basics while specialized courses popularize the knowledge of automotive electronics. Venture courses focus on the processes, developing tools, technical regulations and market analysis in 
enterprises, as engineering practice includes various experiment courses and internships. Now other modules have finished their curriculum construction except venture courses, so that the venture courses module should be strengthened to consolidate the bases.

\subsection{Education for master candidates}

Supporting by the bottom layer, mid layer of the pyramid is engineering education for master candidates. Likewise, the layer has three basic functions, one is to promote engineering capabilities of students, another is to support undergraduate education by means of providing some engineering research subjects etc., and still another is to train predoctoral students for further education. In order to meet the cultivating objectives, three modules are set in this layer including specialized courses, skill training and engineering practice, while practice opportunities come from university-company cooperation projects or branch projects from doctoral research topics.

\subsection{Education for doctoral candidates}

In fact, education for doctoral candidates locates on the top of the pyramid and has a primary objective of future scientist cultivation. However, this layer can provide some engineering tasks to two lower layers, even doctoral students can be the advisers of undergraduates or master candidates. From this point of view, the top layer also plays an important role in the whole engineering talent cultivation system.

\subsection{Layer boundaries}

There is a layer boundary between two layers, which is bidirectional interface. That is to say, upper layers can release research issues or engineering practice opportunities to lower layers. On the contrary, lower layers can release research issues and search for adviser from upper layers to form a R\&D team. This type of boundary not only provides more engineering practice chances to undergraduate students, but greatly stimulates students' enthusiasm for innovation.

In a word, the framework with three layers and two boundaries forms the basic structure of engineering talent cultivation system in major of automotive electronics of Tongji University.

\section{SURVEY OF RELATED VENTURE COURSES}

In order to arrange curriculum of venture courses better, first of all, related curriculum arrangement in other universities or colleges should be investigated[1][2][3]. As a result, few similar curriculums can be found. For example, F.L. Zhu [2] describes the curriculum in FH Essligen of Germany. From table 1, a conclusion can be drawn that this curriculum arrangement shows they take engineering basics, specialized courses and experiment teaching seriously, whereas engineering practice is confined to traditional curriculum design and graduation project.

Table 1 Curriculum of department of automotive engineering in FH Essligen of Germany

\begin{tabular}{|l|l|}
\hline $\begin{array}{l}\text { Engineering } \\
\text { practice }\end{array}$ & $\begin{array}{l}\text { Design course, Engineering practice, } \\
\text { Graduation project }\end{array}$ \\
\hline $\begin{array}{l}\text { Specialized } \\
\text { courses }\end{array}$ & $\begin{array}{l}\text { Vehicle, Thermodynamics and fluid } \\
\text { mechanics, Electronics and measurement } \\
\text { technology, Mechanical vibration, Control } \\
\text { technology, Computing and software } \\
\text { technology, CAE technology, Parts reliability, } \\
\text { Vehicle dynamic analysis, Design course }\end{array}$ \\
\hline $\begin{array}{l}\text { Basic } \\
\text { courses }\end{array}$ & $\begin{array}{l}\text { Mechanics of materials, Electrical engineering } \\
\text { and Information Science, Theoretical } \\
\text { mechanics, Mechanical design, Mathematics, }\end{array}$ \\
\hline
\end{tabular}

Table 2 Curriculum of department of automotive engineering in Tsinghua University

\begin{tabular}{|l|l|}
\hline $\begin{array}{l}\text { Engineering } \\
\text { practice }\end{array}$ & $\begin{array}{l}\text { Vehicle driving practice, Automobile structure } \\
\text { assembly and disassembly, Product design and } \\
\text { process, graduation project }\end{array}$ \\
\hline $\begin{array}{l}\text { Specialized } \\
\text { courses }\end{array}$ & $\begin{array}{l}\text { Introduction of automobile, Automobile } \\
\text { structure, Principle of engine, Theory of } \\
\text { automobile, Automobile development with } \\
\text { energy and environment, Intelligent vehicle, } \\
\text { Ergonomics, Quality engineering, Finite } \\
\text { element analysis, Automotive power } \\
\text { electronics, Automotive noise control, Engine } \\
\text { design, Chassis design, Body design, }\end{array}$ \\
$\begin{array}{l}\text { Automotive electronics and control, Structure } \\
\text { analysis of car body, Fuel cell engine, }\end{array}$ \\
$\begin{array}{l}\text { Principle and matching design of powertrain, } \\
\text { Engine management and optimization, } \\
\text { Intelligent transportation system, Vehicular } \\
\text { test technology, Modern traffic and safety }\end{array}$ \\
\hline $\begin{array}{l}\text { Basic } \\
\text { courses }\end{array}$ & $\begin{array}{l}\text { Fathematics, Physics, Chemistry, } \\
\text { Fundamentals of mechanical design, } \\
\text { Programming, Mechanics of materials, } \\
\text { Engineering Mechanics, Data structure and } \\
\text { algorithm, Control engineering, Electrical and } \\
\text { electronic technology, Hardware technology, } \\
\text { Thermodynamics and fluid mechanics, Heat } \\
\text { transfer, Manufacturing Engineering }\end{array}$ \\
\hline
\end{tabular}

Additionally, domestic related professions seldom have venture courses too. Table 2 shows curriculum arrangement of automotive engineering department in Tsinghua University. The curriculum combines basic courses, specialized courses and research findings in clean energy vehicle together, reflecting solid basis and keeping pace with new results of development and research. However, there is no venture course though some course may have closely 
relation to venture course, for example, "Product Design and Process".

Although there is few precedent of venture course, it plays an important role in engineering talent cultivation system. This type of course is different from traditional theory teaching and practice that it will show general concept of current $\mathrm{R} \& \mathrm{D}$ and production process by lectures, live visits or short term practice, as a rounded preview of real work flow. Venture courses make students and employers closer, while students can be familiar with the relations between theories and real $\mathrm{R} \& \mathrm{D}$ process. In summary, it is necessary to deploy suitable venture courses for our automotive electronics major.

\section{FIRST CASE OF VENTURE COURSES}

In order to make a reasonable course plan based on existing curriculum system and knowledge structure, current curriculum setting should be inspected firstly. The existing courses can be divided into three types: one is specialized theoretical basis such as automobile structure, theory of automobile etc., another involves developing tools training such as design and simulation of control system, and still another mixes theoretical explanation with engineering experience such as in-vehicle network and automotive electronics. These courses mainly focus on primary principles, having no clear description of automotive electronics product development process.

Thus, as a beneficial attempt, "Engineering design of automotive electronics product" now becomes a new formal course in our teaching system. It is a specialized elective course that taught by a vehicle manufacturer and an automotive electronic Part Vendor. The objective of this course is to describe the current process, technology, testing methods and evaluation technology in the development of automotive electronic products from the point of view of vehicle and part makers. Lecturers of the course come from two companies and have sufficient experience in teaching because they are all senior training instructors in their own research fields.

However, as mentioned above, because this course is given by two companies from different manufacturing field, it is necessary to plan the curriculum organization seriously. In order to meet the actual situation of product development and production, a general R\&D model can be taken into consideration. Actually, either a vehicle manufacturer or an automotive electronics Part Vendor will both obey a $\mathrm{V}$-model R\&D process [4] [5] [6], while the difference between them is their developing targets. With a view that vehicle manufacturer is in the front of vehicle development chain, the content of the course should be set according to the general manufacturing process in vehicle enterprise.

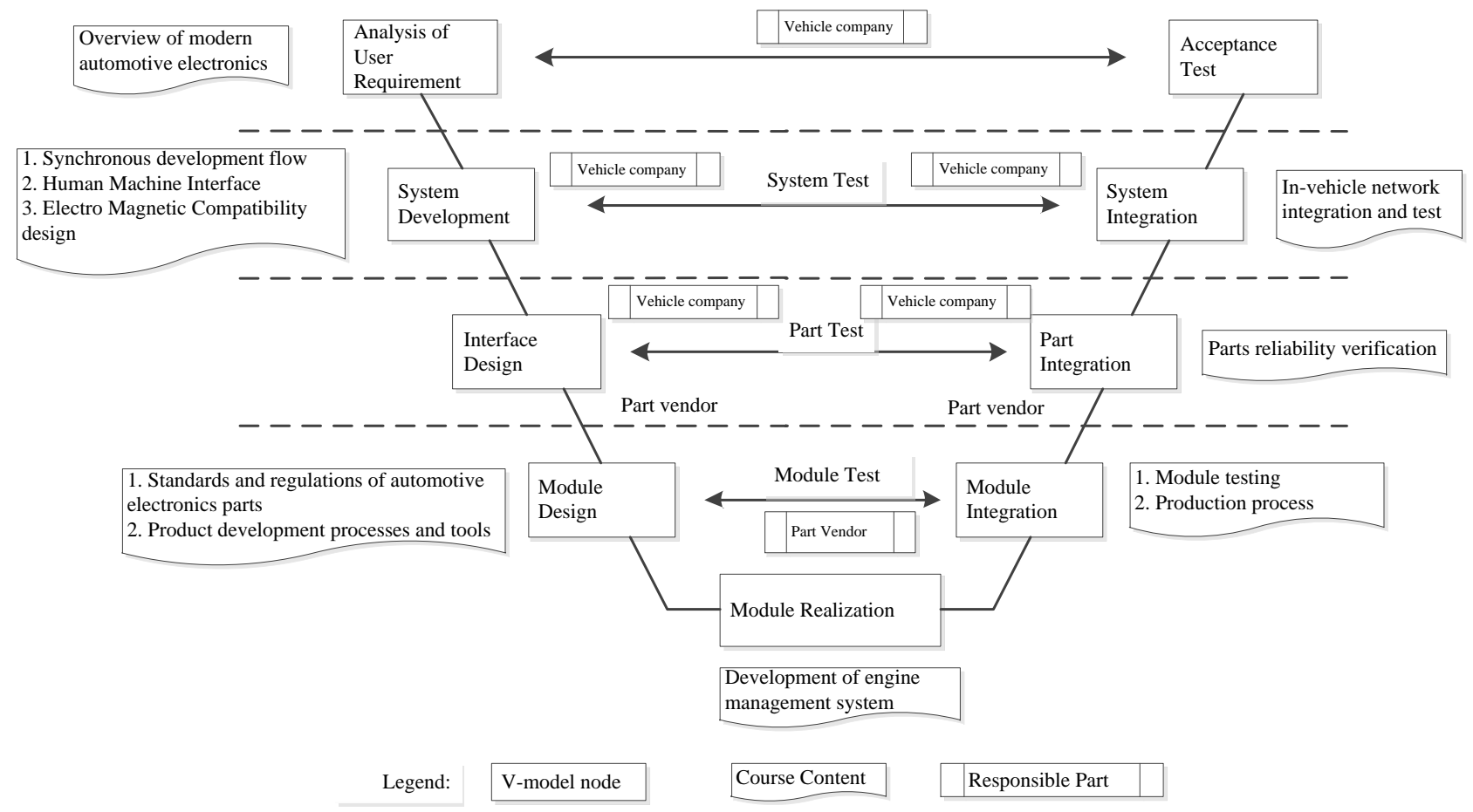

Figure 2 Curriculum setting of "Engineering design of automotive electronics product"

V-model of automotive electronics part development starts from vehicle requirement and definition of part function, interface and performances. Then Part Vendor will define their own product requirement and finish analysis, designing \& implementation, integration, calibration and product test according to a local V-model. Finally, Vehicle Company will complete acceptance 
test and assemble the parts into the vehicle. Now the curriculum setting of "Engineering design of automotive electronics product" can be defined as shown in Figure 2.

In summary, the curriculum setting of "Engineering design of automotive electronics product" not only plays the strong points of two companies, but conform the general developing process in current vehicle related enterprises. The points of knowledge have a reasonable distribution, so that students are satisfied with the course and know the engineering design process of automotive electronics product better.

\section{CONCLUSION}

Based on a compact-structured and layered talent cultivation system, venture courses should be taken into consideration besides the traditional courses and engineering practice. Jointed course is an effective way to optimize students' knowledge structure, while cultivating their engineering consciousness and quality. After 2-3 years' study and training, highly qualified graduates who may be provided with solid theoretical foundation, enough engineering experience and considerably innovative capability can be expected. In summary, jointed engineering talent cultivation system meets the requirements of social economy development for high-level engineering talents.

\section{REFERENCES}

[1] Jian Lin. 2011. Research on Excellent Engineer Education program. Research on Higher Engineering Education, vol (4): $10-17+57$

[2] Fanglai Zhu. 2009. Enlightenment on Bachelor Degree Curriculum System of German FH Essligen. Journal of Shenzhen Polytechnic, vol (4): 54-59

[3] Guoqing Gong. 2012. Analysis and Enlightenment on Curriculum System of Major of Automotive Engineering in British. China Electric Power Education, vol (25): 18$19+21$

[4] Haifengdai \& Xuezhe Wei \& Zechang Sun. 2006. V-model and its Applications in Modern Automotive Electronics System. Mechanical and Electrical Integration, vol (6): 2024

[5] Baixue Fu \& Xufeng Pan. 2008. Modern Automotive Electronics (Edition 2). Beijing Institute of Technology Press

[6] Jorg Schauffele \& Thomas Zurawka, translated by Roger Carey, copyright 2005, Automotive Software Engineering Principles, Processes, Methods and Tools, SAE International Warrendale,pa. 